\title{
Linguistic and cultural aspect of the meaning in the texts of caricatures on protests in Hong Kong (based on English- language publications)
}

\author{
Natalya Saburova ${ }^{1 *}$, Aysen Mikhailov², Klavdia Fedorova ${ }^{1}$ \\ ${ }^{1}$ North-Eastern Federal University named after M.K. Ammosov, 58 Belinsky str., Yakutsk (Republic of Sakha), 677000, Russian \\ Federation \\ ${ }^{2}$ Qiqihar University, Institute of Humanities and Natural Sciences, Linhua Rd, Jianhua District, Qiqihar, Heilongjiang, 161006, People's \\ Republic of China
}

\begin{abstract}
The paper is devoted to the analysis of the linguistic and cultural aspect of caricature texts from the point of view of meaning using the example of protests in Hong Kong represented by the Englishlanguage media. The theoretical review considers such terms and concepts as political caricature, creolized text, linguistic cultural aspect and presuppositions. Political caricature is interpreted as a creolized text, which is an element of political discourse, which meaning is realized based on certain presuppositions, or background knowledge, which in turn is updated through a number of speech and stylistic means. As an example the analytical part of the paper provides analyses of five English-language publications on this topic. The analysis allows illustrating the mechanism for the formation and subsequent implementation of meaning at both the speech and iconic levels of a text, and also demonstrates the role of background knowledge in creating and perceiving the meaning of a political caricature.
\end{abstract}

\section{Introduction}

The relevance of the problem discussed in this paper lies in the continued interest of researchers in a related, interdisciplinary approach in analyzing how the language reflects certain situations from different spheres of human experience. From this perspective the problems of linguistic implementation through the linguistic and cultural aspect to a certain degree are particularly interesting.

From this point of view, the object of this study, namely the creolized representation of the aggravated political situation in the aspect of linguistic and cultural analysis, seems particularly relevant. The novelty of the topic is caused by the peculiarities of the material, i.e. the representation of China and Hong Kong in creolized online texts, as well as objective reasons, namely the rapidly growing political and economic role of the People's Republic of China on a global stage. Thus, the purpose is the study of peculiarities of linguistic and cultural elements in the formation of key images of a political conflict in English-language political caricatures describing the protests in Hong Kong.

Within the framework of this paper caricature is considered as some creolized (i.e. consisting of two types of components - verbal and non-verbal) text, often (but not always) depicting an object in a comic or satirical way. At the same time, the combination of verbal and non-verbal (iconic) components determines the peculiarity of the two basic categories of the text, namely integrity and connectivity [1]. Verbal and iconic components form one visual and semantic whole and have a systemic effect on the addressee - by interacting they create a certain effect.

Within the framework of this study the political caricature is defined as a separate genre of political discourse, the specificity of which is that the author does not express himself directly, but presents his point of view on a particular political phenomenon through both linguistic and extralinguistic means [2]. When analyzing the role and peculiarities of the linguistic and cultural aspect in a political caricature, we will consider presuppositions [3], or background knowledge, which greatly contribute to the realization of the meaning of such texts as one of the key concepts. Often, the meaning and humor of caricatures laid down by a caricaturist are fully understood by the recipient due to the presuppositions. At the same time, such an analysis cannot be complete and integral without taking into account the role of linguistic and semantic methods and means.

\section{Materials and Methods}

A political discourse in its narrow sense is the discourse of politicians implemented in the form of government documents, parliamentary debates, party programs, speeches of politicians [4]. The political discourse is also

Corresponding author: natalya_saburova@inbox.ru 
seen as communication within the socio-political sphere in order to find an effective way to solve a political problem, as well as communication in the public sphere to influence the audience with the help of specific information [5]. The political discourse is also defined, in relation to accepted definitions, as texts presented by special speech means, which are connected with those situations of communication that are related to the political sphere of people's life [6]. Based on this definition, we can argue that the political discourse is the same coherent text, but in a political context.

Having considered these definitions, we can conclude that the political caricature is an integral part of the political discourse.

The analysis of the term "caricature" should begin by considering the concept of a "creolized text". The text may include verbal or iconic, i.e. pictorial (Greek eikon image) components, or their combination. In the latter case, the combination of verbal and non-verbal transmission elements creates a mixed type text called a creolized text or a mixed/polycode text. Both components in the creolized text interact to ensure the integrity and coherence of a message. Creolized texts are divided into partially and fully creolized. Partially creolized texts include, for example, newspaper, popular science and literary texts, in which the iconic component is secondary, and the verbal part is mandatory. The caricature, along with posters and advertisements, refers to fully creolized texts, where the verbal component is completely determined by the pictorial series. Besides, a creolized text can be defined as a text which structure is heterogeneous and consists of two parts: verbal and nonverbal. The examples of creolized texts include caricatures, film texts, means of visual propaganda and agitation, advertising texts, comics [7]. Thus, a caricature is a kind of a creolized (consisting of two types of components) text that comically or satirically depicts someone or something.

The combination of verbal and non-verbal (iconic) components in the caricature determines the peculiarity of the basic text categories: integrity and cohesion. These categories are system properties of speech products and serve the basis for the analytical methods used in text linguistics. On the one hand, the means forming these categories belong to the language system, but in most cases are not specific, but acquire specificity in a single text $[8,9]$. This means that the integrity and cohesion categories are also key for a creolized text. Verbal and iconic components form one visual and semantic whole and have a systemic effect on the addressee - interacting, creating a comic effect. Therein lies the integrity of the caricature. Obviously, the cohesion of the caricature as a coherent text consists in the close interaction of its components [10]. Therefore, it is also obvious that the caricature ceases to be a creolized text and completely ceases to be a caricature if it does not contain one of the components - verbal or iconic.

Thus, a political caricature is a separate genre of a political discourse, the specificity of which, unlike the rest, is that the author does not express himself directly, but presents his point of view in relation to a particular political (or related to the field of politics) phenomenon through the interaction of linguistic and extralinguistic means.

One of the key features in creating and perceiving political caricatures is presuppositions. The meaning laid down by a caricaturist in the work is fully understood by the recipient due to the presuppositions. Presuppositions, or background knowledge, are divided into four types: 1) political - knowledge of political events and moods; 2) logical - knowledge of the logical chain in events and relationships; 3) linguistic - knowledge of the language specifics; 4) extralinguistic - erudition in other fields, such as culture, literature, religion and others [3].

The mechanism for creating and perceiving political caricatures is often laid down at the level of certain stylistic means that the author uses to exert a specific influence on the recipient.

Stylistic techniques traditionally used in the creation of caricatures include conundrum, synecdoche, metaphor, irony, animalization and allusion. A conundrum (or play on words) is a stylistic phrase that comically takes advantage of consonant words or phrases often having mutually exclusive meanings. It is possible to build a conundrum on the basis of polysemy, homonymy or homophony. A synecdoche is a stylistic technique most often found in the iconic part of the caricature. It is based on the transfer of the name due to the relationship of part and whole. This technique allows transforming a part into a whole, or vice versa - a whole into a part. The irony in the caricature is often based on the opposition of meanings between the iconic and verbal parts of the caricature. Metaphor is a technique of hidden comparison, most often available in the iconic part of a political caricature. This technique is most often found due to the universal cognitive nature of the metaphoricity mechanism itself. One of the regularly found varieties of a metaphor is animalization, which allows depicting single objects in the form of an animal, which is attributed some generalized qualities and characteristics while symbolizing certain qualities. An allusion, or reference to known and recognizable in the context of political caricature analysis, allows compressing the entire strata of meanings in a single image introduced directly and indirectly into the text.

During the analysis, we selected and reviewed 5 Englishlanguage political caricatures united by the topic of protests in Hong Kong. The selected caricatures were posted on online media sites or on social networks between 2014 and 2019. The discursive analysis of verbal and iconic elements of the text included the identification of all stylistic means (metaphor and animalization, synecdoche, irony, allusion, conundrum), as well as the features of the implementation of the phenomena of linguistic consciousness involved in the text (mythological image, folklore character, religious image, stereotypical image). The analysis also considered and described both the precedent situation and the presuppositions introduced. 


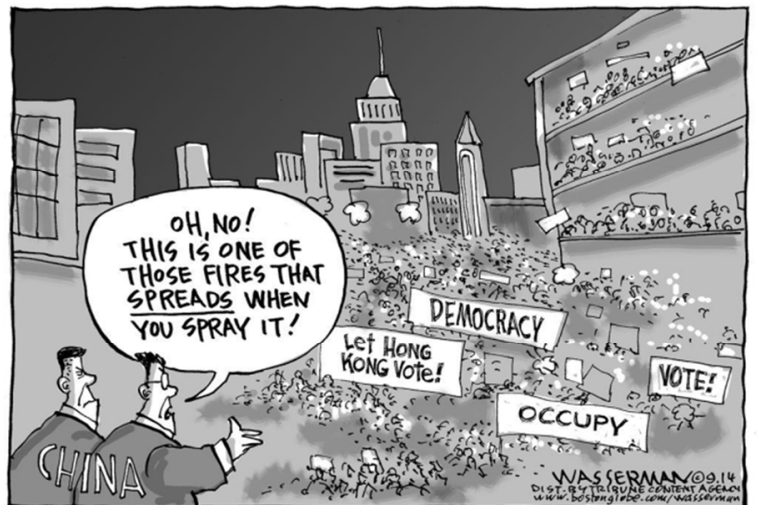

Fig. 1. The English-language caricature by Dan Wasserman posted on September 29, 2014 on the Boston Globe website [11].

Numerous protests against reforms in the local suffrage system, and implying increased control from Beijing, began on September 28, 2014 and lasted 79 days. These protests in the press and social networks became known as the Umbrella Revolution, as protesters used umbrellas as a symbol of protests. The actions began with a short sit-in of the Occupy Central, which involved a regular strike in the central area of the city in front of the government building. Thousands of people poured into the streets after security forces used tear gas against the strikers.

On the caricature we see crowds of protesters with posters "Democracy", "Let Hong Kong vote!", "Vote!", "Occupy". These posters clearly show which protests are at issue. The protesters address two men in suits representing the leadership of China judging by the inscription CHINA on their backs. One of the men tells the other: "Oh, no! This is one of those fires that spreads when you spray it!". It is known that protests were not originally planned as massive protests. However, after the police used tear gas, the conflict escalated rapidly. In the above replica, we can distinguish the reception of a verbal metaphor when protests (which are also identified primarily due to the verbal component) are compared with a fire, and the use of force by the police is compared with fire extinguishing. The image of China is derived here quite generically - in the form of two rather faceless male officials. The facelessness of the PRC representatives can also be interpreted as the external distancing of the Chinese leadership operating through the Hong Kong authorities.

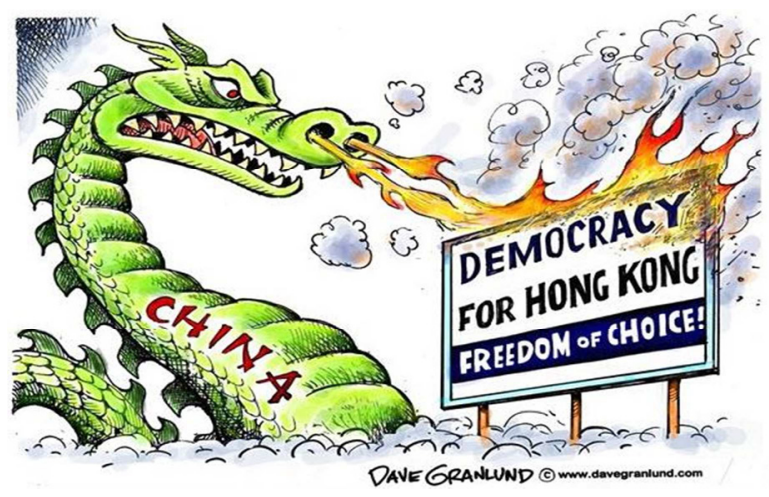

Fig. 2. The caricature by Dave Granlund posted on October 5, 2014 on The English Blog website [12].

The Chinese dragon is a creature of myths and legends, the folklore of the Chinese people. Dragons in Chinese mythology are divided into breeds and groups, and are described in very different ways: sometimes these are creatures with a camel head, deer horns, tiger paws, and sometimes they look more like turtles or fish. However, the most recognizable image of a dragon has long been the image given on this caricature, namely a snake-like creature with scales, fangs and belching fire. This image of the dragon was enshrined in the Chinese Empire symbolizing primarily the power of empire and imperial authorities.

This caricature depicts a huge green dragon belching fire from its nostrils, burning a poster with the inscription: "Democracy for Hong Kong. Freedom of choice!". The animation is implemented through the image of China in the form of a dragon. The inscription "China" on the body of the dragon leaves no doubt that this mythical creature appears in the form of an aggressive and powerful image of China. The iconic metaphor is also realized in the poster that the dragon burns; the meaning of the caricature is quite transparent - China will not allow Hong Kong to promote a democratic movement, and the destruction of the protest movement is also inevitable, like the destruction of a poster by fire. Despite the fact that the Chinese dragon is a traditional symbol of good, in this caricature it is depicted as a hostile creature. The dragon thus allows realizing and rethinking the traditional mythological image. It should be noted that it is the contextual implementation of this image (aggressor) in the caricature that comes to the fore, but the traditional one serves more as a recognizable form.

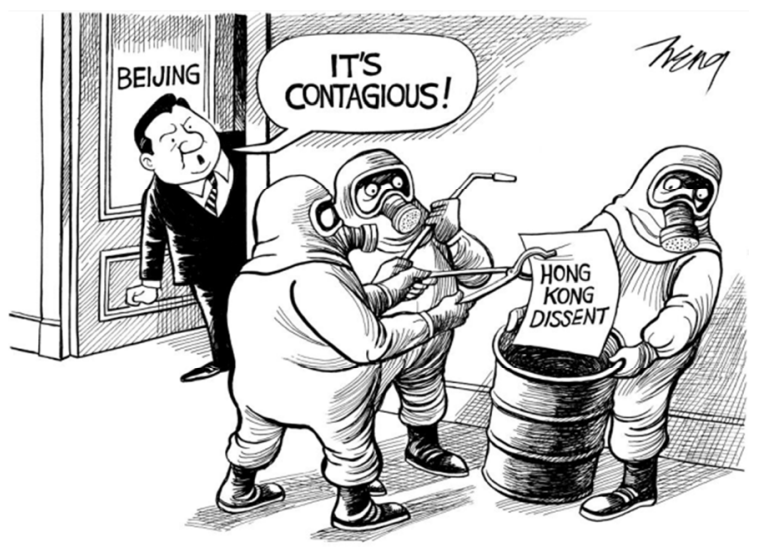

Fig. 3. The caricature by Heng Kim Song posted on The New York Times website on August 19, 2018 [13].

The caricature illustrates the reaction to the efforts of the Hong Kong authorities to cancel the event at which the leader of the Hong Kong National Party, a small political party advocating for the independence of the administrative region, was scheduled to speak. The opposition believes that such actions by the authorities challenge the future of the freedom of speech in the autonomous region. 
Despite the concise black and white design and the general simplicity of the style of this political caricature, the President of China, Xi Jinping, is easily recognized in the central figure (a man in a black suit peeping out from behind the door). He looks from the office with the inscription "Beijing" on the door, which, in our opinion, shows the synecdoche. Thus, the capital of China (itself being the personification of the whole country) is "narrowed" to the size of one room, which symbolizes Beijing. Xi Jinping says, "It's contagious!". Several people in protective suits carefully put a sheet with the inscription "Hong Kong Dissent" into the barrel. Thus, the author brings into the spotlight the fear of the Chinese authorities of any manifestation of the freedom of speech, which implies the presence of different views on things, including politics ("dissent"). China here personifies the Supreme Leader Xi Jinping giving instructions to his followers.

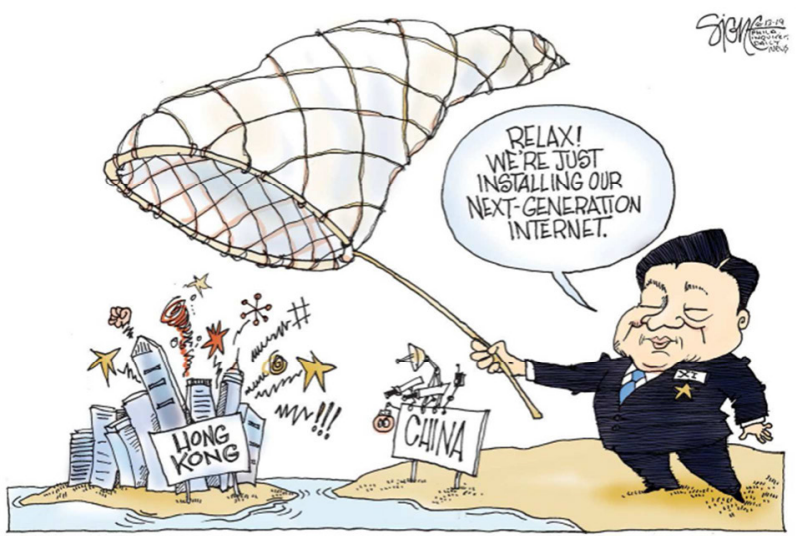

Fig. 4. The caricature by Signe Wilkinson posted on The Philadelphia Inquirer website on June 13, 2019 [14].

Hong Kong Telecom in collaboration with Chinese company Huawei has built infrastructure for high-speed mobile broadband, which will allow the installation of a new 5G network in Hong Kong. Disputes among Hong Kong citizens arose over the fact that the infrastructure responsible for access to $5 \mathrm{G}$ will be largely controlled by the Chinese company Huawei. It should be noted that large Chinese companies, including Huawei, are known for their close cooperation with the PRC government.

$\mathrm{Xi}$ Jinping depicted in the caricature is again well recognized. On his chest we can see a badge with the name - "XI". It is noteworthy that the author intentionally wrote his name in such a way that it coincides with the number 11 written in Roman numerals. Xi Jinping is the eleventh leader of the PRC. The allusion to historical facts is implemented here. In a caricature Xi Jinping addressing a Hong Kong protester, says: "Relax! We're just installing our next-generation Internet. At the same time, the President of China closes the entire Hong Kong with a hoop net. The author thereby uses irony against Xi Jinping, since the depicted actions of the political leader contradict the meaning of the words he utters and make him a liar. The hoop net, being a tool for butterfly fishing, i.e. a silent trap, is a recognizable metaphor that symbolizes the power of Huawei, and therefore the power of the Chinese government in the person of Xi Jinping. Therefore, the image of China here is personified in the form of the country's leader.

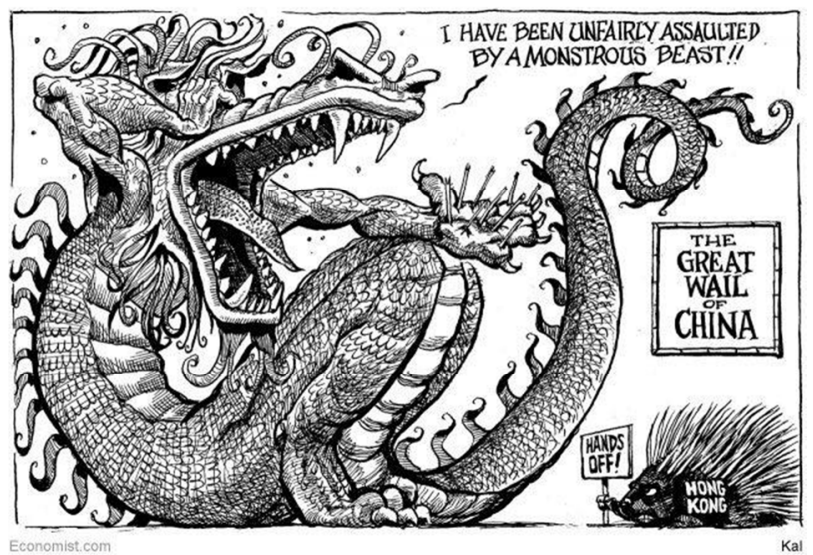

Fig. 5. Kevin Kallaugher's caricature posted on Political Caricature website in Twitter on June 22, 2019 [15].

A new wave of demonstrations in Hong Kong began on March 31, 2019, but it is customary to report the beginning of major protests on June 9, since it was on this day that more than a million citizens poured into the streets. A series of demonstrations against the bill on the extradition of those convicted of participating in protests to the Mainland China lasted all summer until August 18 , when at least 1.7 million people came out to support the movement against the extradition bill. The reason for the protests is the fear of citizens that if the bill is adopted, Hong Kong will come under the jurisdiction of the Mainland China, which will end the autonomy and restriction of the rights of Hong Kong citizens.

This caricature again depicts a Chinese dragon. However, in this picture he shouts in pain: "I have been unfairly assaulted by a monstrous beast!!". The dragon, obviously, was going to grab a porcupine on which it says "Hong Kong" and was injured. The metaphoranimalization technique was used by the author in relation to both sides - China and Hong Kong. A mighty dragon seems to do nothing against a small but prickly porcupine. The sign "Hands off!", which a porcupine holds in its paw, identifies a separate metaphor that likens porcupine spikes to protests powerful enough to protect citizens from the influence of the Mainland China. An element with the inscription "The Great Wall of China" apparently serves as the title of the caricature. Probably, such a name indicates an invisible "wall", which separates the Mainland China and Hong Kong. This barrier does not allow the stronger side touching the weaker side. With this analogy, this image can be considered as another implementation of the metaphor, when the concept of "The Great Wall of China" is used in a figurative meaning. Besides, there is irony in the relationship of the dragon's replica "I have been unfairly assaulted by a monstrous beast!!" and the overall picture. A dragon calling a porcupine a "terrible monster", while he himself can claim to such a definition - this is a deeply ironic image. The image of China in the form of a dragon also refers to redefined mythological images. 


\section{Conclusion}

The discursive analysis of 5 political caricatures from English-speaking authors revealed the implementations of such stylistic techniques as metaphors, of which three are metaphors-animalization (China-dragon and Hong Kong-porcupine); irony, which is found in all five texts; two examples of verbal allusion; and one example of verbal-iconic synecdoche.

It is noteworthy that in the analyzed texts the mythological image (dragon) is actualized not in the traditional (personification of wisdom and good power), but in the situational sense and appears as a hypocritical aggressor attacking smaller and weaker people.

It should also be noted that all English-language texts selected for the analysis express pro-Hong Kong attitude and sympathy for the protesting Hong Kong as a small but brave country suffering from the brutal and unjust aggression of a huge and strong China (figures of people with posters, a banner with pro-democratic slogans, a porcupine with a poster "Hands Off").

The PRC leader in the analyzed texts appears quite recognizable, but at the same time, at both the verbal and iconic level, such features as craze, hypocrisy are attributed to him (he throws a hoop net on Hong Kong saying that he is doing good) and the ability to act underhandedly (he looks from behind the door, inciting subordinates).

The subject matter of protests (social and political) does not lose its relevance, and the ways in which it is reflected in modern media are still of great interest to the study. Due to its structural and semantic features the political caricature is especially interesting from the point of view of the analysis of the linguistic and cultural aspects, namely the mechanism of speech and iconic implementation of the system of presuppositions, which are largely based on traditional, mythological and culture-specific images. For this reason, it seems necessary to continue the analysis of English-language caricatures on the subject of protests in Hong Kong, as well as to consider, analyze and compare how this conflict is presented by the other side, namely the Chinese media. It seems that such a study may be of interest in terms of a multidisciplinary approach to linguistic and linguistic-cultural issues.

\section{References}

1. E.E. Anisimova, Linguistics of the text and intercultural communication (based on creolized texts) (Academia, Moscow, 2003)

2. E.A. Artemova, Caricature as a genre of political discourse, PhD thesis (Volgograd State SocioPedagogical University, Volgograd, 2002)

3. E.V. Seredina, Features of the expression of the author's position in the American political caricature, Modern problem of linguistics, literary criticism, intercultural communication and linguodidactis collection of scientific articles, 315-318 (2014)
4. T.A. van Dijk, Language. Cognition, Communication (Moscow, Progress, 1989)

5. S.N. Generalova, The concept of "political discourse in the linguocultural paradigm", Pushkin Leningrad State University Journal, 5(2), 95-101 (2010)

6. A.A. Karamova, Structure of political discourse, Modern Problems of Science and Education, 2, 534 (2014)

7. N.S. Valgina, Text theory (Moscow, Logos, 2003)

8. I.V. Trufanova, On the differentiation of concepts: speech act, speech genre, speech strategy, speech tactics, Philological sciences, $\mathbf{3}$, 56-65 (2001)

9. V.B. Kasevich, Semantics. Syntax. Morphology (Nauka, Moscow, 1988)

10. O.A. Voronina, Caricature as a kind of creolized texts, Bulletin of The Center for International Education of The Moscow State University. Philology. Culturology. Pedagogics. Method, 2, 15 (2009)

11. D. Wasserman, Editorial caricature: Hong Kong protests, retrieved from: https://www.bostonglobe.com/opinion/2014/09/2 9/editorial-caricature-hong-kongprotests/nq1TIHmDL4Q31s7wNQ2vgK/story.htm 1

12. D. Granlund, Caricature: The Chinese Dragon, retrieved from: https://www.englishblog.com/2014/10/caricaturethe-chinesedragon.html\#.XtB7GIsufIU

13. Heng Kim Song, Sanitizing Hong Kong of Free Speech, retrieved from: https://www.nytimes.com/2018/08/19/opinion/ho ng-kong-independence-china-free-speech.html

14. S. Wilkinson, Political Caricature: Hong Kong's Chinese internet, retrieved from: https://www.inquirer.com/opinion/caricatures/hon g-kong-china-freedom- 20190613.html

15. K. Kallaugher, Kal on protests in Hong Kong over Chinese extradition - political caricature gallery in London, retrieved from: https://twitter.com/Caricature4sale/status/114214 0662147624960/photo/1 